\title{
Makarnalık buğday (Triticum durum Desf.) çeşitlerinin doku kültürü parametrelerine tepkisi
}

\section{Response of some durum wheat (Triticum durum Desf.) genotypes on tissue culture parameters}

\author{
Berk BENLİOĞLU(i), Nilüfer KOÇAK(i), Melehat AVCI BİRSIN(i) \\ Ankara Üniversitesi, Ziraat Fakültesi, Tarla Bitkileri Bölümü, 06110, Dışkapı, Ankara, Türkiye \\ Sorumlu yazar (Corresponding author): B. Benlioğlu, e-posta (e-mail): benliogluberk@hotmail.com \\ Yazar(lar) e-posta (Authore-mail): nkocak@ankara.edu.tr, mbirsin@yahoo.com
}

\section{MAKALE BİLGISİ}

Alınıs tarihi 10 Temmuz 2019

Düzeltilme tarihi 28 Şubat 2020

Kabul tarihi 28 Şubat 2020

\section{Anahtar Kelimeler:}

Embriyo kültürü

Genotipik etki

Makarnalık buğday

Triticum durum

Rejenerasyon

\begin{abstract}
$\ddot{O Z z}$
$\mathrm{Bu}$ araştırmada Türkiye makarnalık buğday tarımında öneme sahip ve biyotik-abiyotik stres faktörlerine yüksek adaptasyon özelliklerinden dolayı sslah programlarında ebeveyn olarak yararlanılan 13 makarnalık buğday genotipi (Altın 40/98, Ankara 98, Berkmen-469, Çeşit 1252, Eminbey, İmren, Kızıltan-91, Kunduru 414/44, Kunduru 1149, Meram 2002, Mirzabey 2000, Selçuklu 97, Yelken 2000) kullanılmıștır. Bu genotiplerin, kallus kültürü parametrelerine olan tepkileri belirlenerek biyoteknolojik karakterizasyonları yapılmıştır. Olgun embriyoların kullanıldığı araştırmada, steril koşullarda tohumlardan çıkartılan embriyolar $2 \mathrm{mg} \mathrm{l}^{-1}$ 2,4-D ve MS mineral maddelerini içeren katı besin ortamında kültüre alınmıştır. Gelişen kalluslar, sürgün ve kök oluşturabilmeleri için hormon içermeyen MS ortamına transfer edilmiștir. 13 makarnalık buğday genotipinin olgun embriyoları karşılaştırıldığında; kallus ağırlığı, rejenerasyon kapasitesi ve kültür etkisi parametrelerinde genotipler arasındaki farkın $\mathrm{P}<0.01$ düzeyinde önemli olduğu belirlenmiştir. Test edilen 13 makarnalık buğday genotipinden Berkmen-469, Kızıltan-91 ve Eminbey en yüksek rejenerasyon kapasitesi ve kültür etkisi değerlerinin oluşturarak, rejenerasyon yeteneği en yüksek kallusları meydana getirmişlerdir. Bu genotiplerin doğrudan gen aktarılabilme potansiyellerinin diğer genotiplere göre daha yüksek olduğu ve önümüzdeki dönemlerde biyoteknolojik yöntemlerle dayanıklı çeşit geliştirilmesine taban oluşturabilecek genotipler olduğu belirlenmiştir.
\end{abstract}

\section{ARTICLE INFO}

Received 10 July 2019

Received in revised form 28 February 2020 Accepted 28 February 2020

\section{Keywords:}

Embryo culture

Genotypic effect

Durum wheat

Triticum durum

Regeneration

\begin{abstract}
The research was carried out using 13 durum wheat genotypes Altın 40/98, Ankara 98, Berkmen-469, Çeşit 1252, Eminbey, İmren, Kızıltan-91, Kunduru 414/44, Kunduru 1149, Meram 2002, Mirzabey 2000, Selçuk 97, Yelken 2000 that are important in breeding programs as parents due to their tolerance against biotic-abiotic stresses and high adaptation features. Biotechnological characterization of these genotypes was made by determining their responses to callus culture parameters. The study used mature embryos, obtained from their seeds under sterile conditions that were cultured on agar solidified MS medium containing $2 \mathrm{mg} \mathrm{l}^{-1}$ 2,4-D The developed calli were transferred to MS medium without any hormones to form shoots and roots and were compared among themselves with significant difference among genotypes in the parameters of callus weight, regeneration capacity (\%) and culture effect at the level of $\mathrm{P}<0.01$. Berkmen-469, Kizltan-91 and Eminbey had the highest regeneration capacity and culture effect values among 13 durum wheat genotypes that induced maximum callus regeneration. These genotypes were found to have higher genetic transformation ability and could form the basis for the development of resistant varieties with biotechnological methods in future.
\end{abstract}




\section{Giriş}

Dünyada ve ülkemizde en fazla kültürü yapılan bitki olan buğday, insan beslenmesinin temelini oluşturmaktadır. Buğday; ekmek, makarna, bulgur, irmik, bisküvi gibi gıda maddelerinin üretiminde kullanılmaktadır. Adaptasyon sınırları geniş ve birim alan verimi daha yüksek olduğu için toplam buğday ekim alanların büyük bir kısmını ekmeklik buğdaylar olușturur. Makarnalık buğday ise daha özel iklim koşullarına gereksinim duyduğundan daha dar alanlarda üretilmektedir. Ülkemizde 2019 yılında yaklaşık 7.3 milyon ha olan toplam buğday ekim alanının 1.2 milyon ha'lık kısmını makarnalık buğdaylar kapsamaktadır. 2004 yılında 2.1 milyon ha olan makarnalık buğday ekim alanında son 15 yılda dramatik bir düşüş gerçekleşmiştir (TÜİK 2019). Türkiye makarnalık buğdayın gen merkezlerindendir ve ekolojik olarak kaliteli makarnalık buğday üretimine son derece uygundur (Bozkurt 2012). Dünya'nın önemli makarnalık buğday üretici ülkelerinden biri olan Türkiye makarna üretiminde de öncü ülkelerdendir ve 797.966 ton ile Dünya'da İtalya'dan sonra en fazla makarna ihracatı gerçekleştiren ülke konumundadır (FAO 2019).

Yeryüzünde ekim alanlarının marjinal sınırlara ulaşması, tarım alanlarının amaç dışı kullanılması, yanlış tarımsal uygulamalar ve erozyon sonucu tarım alanlarının verimsizleşmesi işlenen tarım alanlarını daraltmaktadır. Dünya nüfusunun artmasına paralel olarak tarım alanlarının azalması, artan nüfusun besin ihtiyacının karşılanması için birim alan veriminin artırılması zorunludur. Bunun için ise; abiyotik ve biyotik streslere toleranslı ve kaliteli yeni çeşitlerin geliştirilmesi gerekmektedir.

Klasik bitki ıslahı yöntemlerinin uzun yıllar sürmesi ve yoğun iş gücü gerektirmesi yeni çeşitlerin geliştirilmesini sınırlandıran en önemli bir faktördür. Biyoteknolojik yöntemlerin gelişmesi klasik ıslahı yöntemlerinde zamandan büyük ölçüde kazanıma ve uygulamada karşıllaşılan sorunların aşılmasına olanak sağlamıştır. Bilindiği gibi biyoteknolojik yöntemlerin ilk aşaması doku kültürüdür. Doku kültüründe temel amaç, sağlıklı ve yüksek oranda bitki rejenerasyonu ve hızlı çoğaltımın yapılabilmesidir. Biyoteknolojik tekniklerden yararlanılarak gen aktarmada önemli bir aşama olan kallus oluşumu ve bitki rejenerasyonunda başarı başta genotip olmak üzere kültür ortamının içeriği, eksplant kaynağı ve büyüme düzenleyicilerinin miktar ve yapısı gibi birçok faktöre bağlıdır (Tuberosa ve ark. 1988; Ahmet ve Adak 2007; Farshadfar ve ark. 2012a; Mahmood ve ark. 2012; Özgen ve ark. 2017; Miroshnichenko ve ark. 2019). Transgenik hatların transformasyonu ve gelişiminin başarılı olabilmesi için rejenerasyon yeteneği yüksek genotiplerin olması gereklidir (Swati ve ark. 2019). Buğday transformasyon çalıșmalarında, doku kültüründe olumlu yanıt veren bir veya iki spesifik buğday genotipi kullanılmaktadır (Witrzens ve ark. 1998). Bu genotipik bağımlılığı ortadan kaldırmak için buğday çeşitlerinin gen aktarılabilme yatkınlıklarının bilinmesi gerekmektedir.

$\mathrm{Bu}$ çalışmanın amacı Türkiye'de makarnalık buğday tarımında önemli, adaptasyon alanı geniş, biyotik ve abiyotik stres faktörlerine toleranslı ve 1slah programlarında anaç olarak kullanılan 13 makarnalık buğday çeşidinin olgun embriyolarını kullanarak bu çeşitlerin kallus oluşumu ve bitki rejenerasyonu yeteneğini belirlemek ve olası gen aktarma çalışmaları için potansiyellerini saptamaktır.

\section{Materyal ve Yöntem}

Araştırma 2018-2019 sezonunda yürütülmüştür. Materyal olarak Türkiye'de yetiştirilen ve genitör olarak önem taşıyan 13 adet makarnalık buğday çeşidinin (Altın 40/98, Ankara 98, Berkmen-469, Çeşit 1252, Eminbey, İmren, Kızıltan-91, Kunduru 414/44, Kunduru 1149, Meram 2002, Mirzabey 2000, Selçuklu 97, Yelken 2000) olgun embriyoları kullanılmıştır. Olgun tohumlar Türkiye Tohum Gen Bankası'ndan temin edilmiştir.

Olgun tohumlar sterilizasyon için \%70'lik (v/v) alkolde $5 \mathrm{~d}$ temizlenmiş ve steril saf su ile yıkanmış, daha sonra \%5'lik sodyum hipokloritte $(\mathrm{NaClO}) 30 \mathrm{~d}$ muamele edilip, birkaç kez steril saf su ile durulanmıștır. Yüzey sterilizasyonu tamamlanan tohumlar $33^{\circ} \mathrm{C}^{\prime}$ deki su banyosunda 2 saat bekletilerek yumuşatılmıştır. Kallus oluşumu için embriyolar; $2 \mathrm{mg} \mathrm{l}^{-1}$ 2,4-D, MS (Murashige ve Skoog 1962), $20 \mathrm{~g} \mathrm{l}^{-1}$ sakkaroz ve 7 $\mathrm{g} \mathrm{l}^{-1}$ agar içeren besin ortamlarına kalkancık yukarı bakacak şekilde yerleştirilmiştir. Petriler kalluş oluşumu için $25 \pm 1^{\circ} \mathrm{C}$ 'de karanlıkta inkübatöterde 15 gün bekletilmiştir. Bu süre sonunda kallus oluşum oranı ve kallus ağırlığı parametreleri elde edilmiştir. Elde edilen kalluslar sürgün oluşumu için MS-0 besi ortamına aktarılarak 4 hafta $25 \pm 1{ }^{\circ} \mathrm{C}$ 'de 16 saat aydınlık (1500 lux)/8 saat karanlıkta bırakılmıştır (Özgen ve ark. 2017). Ardından rejenere olan kalluslar daha iyi gelişebilmeleri için MS-0 ortam içeren jarlara aktarılmış ve $25 \pm 1^{\circ} \mathrm{C}$ 'de 16 saat aydınlık (1500 lux) / 8 saat karanlıkta rejenerantların gelişmeleri sağlanmıștır. Bu süre sonunda rejenere olan kalluslar sayılarak "Rejenerasyon Kapasitesi" ve "Kültür Etkisi" parametreleri saptanmıştır (Özgen ve ark. 1998).

Kallus oluşumu (\%), kültürün 15 . gününde her petride kallus oluşturan embriyoların sayısının toplam embriyo sayısına oranlanmasıyla; kallus ağırlığı $(\mathrm{g})$ ise kültürün 15. gününde embriyolarda oluşan kallusların tartılmasıyla bulunmuştur. Rejenerasyon kapasitesi (\%), rejenere olan kallusların oluşan kallus sayısına oranlanmasıyla ve kültür etkisi (\%) ise, rejenere olan kallusların kültüre alınan embriyo sayısına oranıyla elde edilmiştir (Sayar ve ark. 1999).

Deneme tesadüf parselleri deneme desenine göre 3 tekrarlı kurulmuştur. Her uygulama için petri kaplarına 10'ar adet olgun embriyo yerleştirilmiştir. Elde edilen veriler JMP-12 istatistik paket programı kullanılarak analiz edilmiş, çeşitler arasındaki farklılığın belirlenmesi için de Duncan testi yapılmıştır (Steel ve ark. 1980).

\section{Bulgular ve Tartışma}

Makarnalık buğdayda olgun embriyo kültüründe incelenen parametrelerden elde edilen verilerle yapılan varyans analizi sonuçları Çizelge 1'de verilmiştir. Varyans analizi sonuçlarına göre; kallus oluşumu bakımından istatistiki olarak önemli bir farklılık bulunmazken, kallus ağırlığı, rejenerasyon kapasitesi ve kültür etkisi parametrelerinde çeşitler arasındaki farklılık istatistiki olarak $\mathrm{P}<0.01$ düzeyinde önemli bulunmuştur (Çizelge 1). Çeşitlerin incelenen parametrelerdeki ortalama değerleri ve çeşitler arasındaki farklılığın belirlenmesi için yapılan Duncan testi sonuçları Çizelge 2'de gösterilmiştir.

Olgun embriyolardan kallus oluşumunun başlaması kültürün 4. gününde gerçekleşmiştir. Çeşitlerden, beyaz renkli, gevşek-sulu ve koyu krem renkli, kompakt-katı olmak üzere iki 
Çizelge 1. Makarnalık buğday genotiplerinin doku kültürü parametrelerine tepkisine ilişkin varyans analiz sonuçları.

Table 1. Variance analysis results for the durum wheat genotypes in response to tissue culture parameters.

\begin{tabular}{|c|c|c|c|c|c|}
\hline \multirow{2}{*}{ Varyasyon Kaynakları } & \multirow{2}{*}{ SD } & \multicolumn{4}{|c|}{ F Değerleri } \\
\hline & & Kallus oluşumu & Kallus Ă̆ırlığı & Rejenerasyon Kapasitesi & Kültür Etkisi \\
\hline Genotip & 12 & $0.649 \mathrm{~ns}$ & $23.963 * *$ & $5.425 * *$ & $3.269 * *$ \\
\hline Hata & 26 & - & - & - & \\
\hline Toplam & 38 & - & - & - & \\
\hline
\end{tabular}

Çizelge 2. Makarnalık buğday genotiplerinin doku kültüründeki ortalama değerleri.

Table 2. The mean values of durum wheat genotypes in tissue culture.

\begin{tabular}{|c|c|c|c|c|c|}
\hline Genotipler & Kallus Tipi & Kallus oluşumu (\%) & Kallus Ağırığg (g) & Rejenerasyon Kapasitesi $(\%)^{1}$ & Kültür Etkisi $(\%)^{2}$ \\
\hline Altın-40/98 & $\mathrm{L}$ & 100.0 & $1.180 \mathrm{a}^{3}$ & $66.6 \mathrm{fg}$ & $66.6 \mathrm{c}-\mathrm{e}$ \\
\hline Ankara-98 & $\mathrm{L}$ & 100.0 & $1.306 \mathrm{a}$ & $70.0 \mathrm{~d}-\mathrm{g}$ & $70.0 \mathrm{c}-\mathrm{e}$ \\
\hline Berkmen-469 & $\mathrm{C}$ & 96.7 & $0.494 \mathrm{~g}$ & $100.0 \mathrm{a}$ & $96.7 \mathrm{a}$ \\
\hline Çeşit -1252 & $\mathrm{L}$ & 96.7 & $0.810 \mathrm{~cd}$ & 85.9 a-d & 80.0 a-d \\
\hline Eminbey & $\mathrm{C}$ & 96.7 & $0.744 \mathrm{de}$ & $86.3 \mathrm{a}-\mathrm{c}$ & $80.0 \mathrm{a}-\mathrm{d}$ \\
\hline İmren & $\mathrm{C}$ & 96.7 & $0.632 \mathrm{e}-\mathrm{g}$ & $68.50 \mathrm{e}-\mathrm{g}$ & $66.7 \mathrm{c}-\mathrm{e}$ \\
\hline Kızıltan-91 & $\mathrm{C}$ & 93.3 & $0.677 \mathrm{~d}-\mathrm{f}$ & $96.3 \mathrm{ab}$ & $90.0 \mathrm{ab}$ \\
\hline Kunduru -1149 & $\mathrm{L}$ & 100.0 & $0.890 \mathrm{bc}$ & $66.6 \mathrm{fg}$ & $66.6 \mathrm{c}-\mathrm{e}$ \\
\hline Kunduru-414/44 & $\mathrm{C}$ & 96.7 & $0.558 \mathrm{fg}$ & $75.9 \mathrm{c}-\mathrm{f}$ & $73.3 \mathrm{~b}-\mathrm{e}$ \\
\hline Meram-2002 & $\mathrm{L}$ & 96.7 & $0.924 \mathrm{bc}$ & $58.9 \mathrm{~g}$ & $56.7 \mathrm{de}$ \\
\hline Mirzabey & $\mathrm{L}$ & 100.0 & $0.973 \mathrm{~b}$ & $63.3 \mathrm{fg}$ & $63.3 \mathrm{de}$ \\
\hline Selçuklu & $\mathrm{L}$ & 96.7 & $0.798 \mathrm{~cd}$ & $83.3 \mathrm{~b}-\mathrm{e}$ & 80.0 a-d \\
\hline Yelken -2000 & $\mathrm{L}$ & 96.7 & $0.730 \mathrm{c}-\mathrm{g}$ & $68.9 \mathrm{e}-\mathrm{g}$ & 80.0 a-d \\
\hline Ortalama & & 97.4 & 0.825 & 74.8 & 76.21 \\
\hline
\end{tabular}

L: Gevşek ve sulu tip, C: Compakt ve nodular tip, ${ }^{1}$ : (Rejenere kallus sayısı) / (Oluşan kallus sayısı) x $100,{ }^{2}$ : (Rejenere kallus sayısı) / (Kültüre alınan eksplant sayısı) x $100,{ }^{3}:$ Aynı harfleri taşıyan ortalamalar arasındaki fark istatistik olarak önemsizdir.

L: Loose and fragile type, C: Compact and nodular type, ${ }^{1}$ : Number of regenerable calli (Nodular calli with green spots) / number of calli induced $x$ 100, ${ }^{2}$ : (Number of regenerable calli) / (Number of embryos cultured) x 100, ${ }^{3}$ : The average values assigned the same letters are statistically insignificant.

formda kallus oluşumu gözlemlenmiştir (Çizelge 2). Kültürün 15. gününde çeşitlerin kallus oluşumu ve kallus ağırlıkları hesaplanmıştır ve kallusların ortalama çapları 5-6 mm olarak ölçülmüştür. Denemelerde kullanılan çeşitlerin hepsi yüksek oranda kallus oluşturmuş olup ortalamaları \%93.3 ve \%100 arasında değişmiştir (Çizelge 2).

Kallus ağırlığı bakımından; çeşitlerin ortalaması $0.825 \mathrm{~g}$ olarak hesaplanmıştır. Ankara-98, $1.306 \mathrm{~g}$ ile en yüksek ağırlığı oluştururken, Berkmen-469 çeşidi ise $0.494 \mathrm{~g}$ ile en az ağırlığına sahip olmuştur. Duncan sınıflandirmasına göre çeşitler 5 farklı sınıf oluşturmaktadır (Çizelge 2). Çeşitlerin oluşturdukları kallus miktarına genotipik etkinin yüksek olduğu elde edilen sonuçlar ile anlaşılmaktadır.

Kültür başlangıcından 15 gün sonra rejenerasyon ortamına aktarılan kalluslarda, 16 saat aydınlık 8 saat karanlık fotoperiyod koşullarında 2-3 gün içerisinde yeşil noktacıklar oluşmaya başlamıştır (Şekil 1). Rejenerasyon kapasiteleri bakımından çeşitler karşılaştırıldığında; en yüksek rejenerasyon kapasitesinin \%100 ile Berkmen-469 çeşidinde, en düşük rejenerasyonun ise \%66.6 ile Altın-40/98 çeşidinde olduğu görülmektedir. Çeşitlerin ortalama rejenerasyon kapasitesi ise $\% 74.8$ olarak hesaplanmıştır. Çeşit ortalamalarının karşılaştırıldığı Duncan testinde ise beş farklı grup ortaya çıkmıştır (Çizelge 2). Genotiplerin rejenerasyon yeteneklerinin oluşturdukları kallus tipine bağlı olarak değişiklik gösterdiği, krem renkli ve katı kallusların daha fazla rejenere olduğu belirlenmiştir. $\mathrm{Bu}$ veriler; rejenerasyon kapasitesinin genotipe bağl1 olarak önemli oranda değiştiğini göstermektedir. Bulgularımız; ekmeklik buğdayda (Özgen ve ark. 2001; Zale ve ark. 2004; Ahmet ve Adak 2007; Farshadfar ve ark. 2012a;
Farshadfar ve ark. 2012b; Delporte ve ark. 2014; Aadel ve ark. 2016; Malik ve ark. 2017; Jasdeep ve ark. 2019), makarnalık buğdayda (Özgen ve ark. 1996; Bajji ve ark. 2000; Gonzales ve ark. 2001; Pellegrineschi ve ark. 2004; Grigoryeva ve Shletser 2006; İbrahim 2012; Hakam ve ark. 2014), arpada (Przetakiewicz ve ark. 2003), yulafta (Birsin ve ark. 2001) ve tritikalade (Birsin ve Özgen 2004) yapılan doku kültürü çalışmalarında rejenerasyon kapasitesinin genotipten önemli ölçüde etkilendiğini gösteren sonuçlarla uyumludur.

Kültür etkisine göre makarnalık buğday çeşitleri karşılaştırıldığında; en düşük oranın \%66.6 ile Altın-40/98 çeşidinde, yüksek oranın ise ve \%96.7 ile Berkmen-469 çeşidinde oluştuğu görülmektedir. Çeşitlerin ortalamaları \%76.2 olarak hesaplanmıştır. Duncan gruplandırmasında çeşitler 7 gruba ayrılmıştır. Kültür etkisinin genotipden etkilendiğini gösteren bulgularımız; buğdayda (Özgen ve ark. 2001; Birsin ve ark. 2001; Haliloğlu 2002; Ahmet ve Adak 2007) tritikalede (Birsin ve Özgen 2004) ve aegilopsda (Özgen ve ark. 2017) yapılan çalışmalardan elde edilen sonuçlarla benzerlik göstermektedir.

Makarnalık buğdayın olgun embriyolarının kullanıldığ çalışmada doku kültürü parametrelerinden elde edilen veriler arasında yapılan korelasyon analizi sonuçları Çizelge 3'te verilmiştir. Çizelge 3 'te görüldüğü gibi; karakterler arasındaki en yüksek ilişki $\left(\mathrm{r}=0.889^{* *}\right.$ ve $\left.\mathrm{P}<0.01\right)$ rejenerasyon kapasitesi ile kültür etkisi parametreleri arasında ortaya çıkmıştır. Rejenerasyon kapasitesi ile kültür etkisi arasında pozitif ve önemli ilişki olduğunu gösteren bulgularımız, yulafta $(r=0.678)$ (Birsin ve ark. 2001) ve buğdayda ( $\mathrm{r}=0.857$ ) (Acar 2006) elde edilen sonuçlarla 


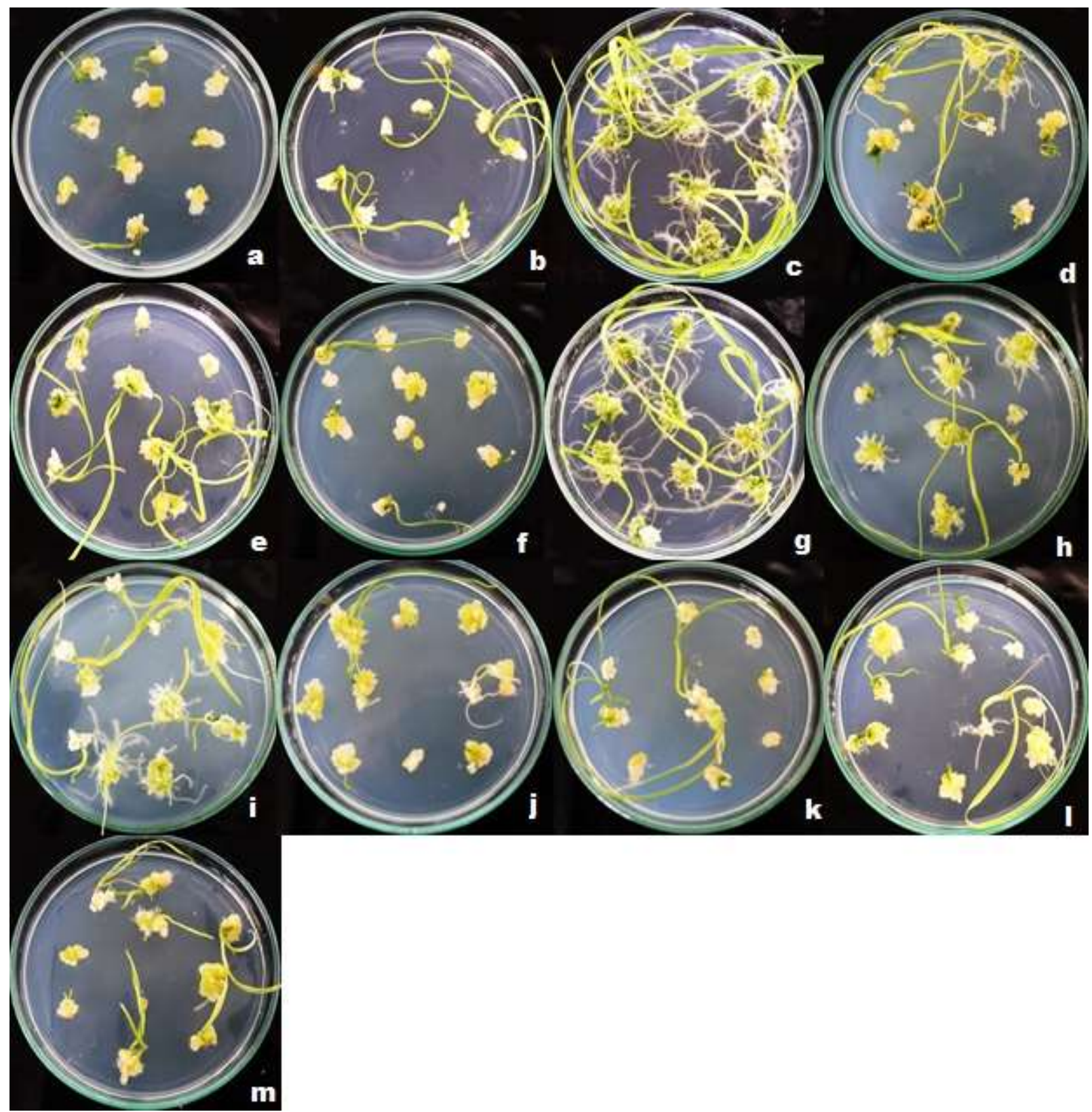

Şekil 1. Makarnalık buğday çeşitlerinin olgun embriyo kültüründeki rejenerantları (a: Altın 40/98, b: Ankara-98, c: Berkmen-469, d: Çeşit-1252, e: Eminbey, f: İmren, g: Kızıltan-91, h: Kunduru-1149, i: Kunduru 414/44, j: Meram-2002, k: Mirzabey-2000, 1: Selçuklu-97 ve m: Yelken-2000).

Figure 1. Regenerants of durum wheat varieties in mature embryo culture (a: Altın 40/98, b: Ankara-98, c: Berkmen-469, d: Çeşit-1252, e: Eminbey, f: Imren, g: KızıItan-91, h: Kunduru-1149, i: Kunduru 414/44, j: Meram-2002, k: Mirzabey-2000, I: Selçuklu-97 ve m: Yelken-2000).

Çizelge 3. İncelenen parametreler arasındaki korelasyon katsayısı değerleri.

Table 3. Correlation coefficient values between the examined parameters.

\begin{tabular}{lcccc}
\hline \multirow{2}{*}{ Karakterler } & \multicolumn{4}{c}{ Karakterler arasindaki Korelasyon Katsayısı } \\
\cline { 2 - 5 } & 1 & 2 & 3 & 4 \\
\hline (1) Kallus oluşumu (\%) & - & $0.339^{*}$ & -0.239 & -0.131 \\
(2) Kallus Ağırlı̆̆ (g) & - & - & $-0.422^{*}$ & $-0.405^{*}$ \\
(3) Rejenerasyon Kapasitesi (\%) & - & - & - & $0.889^{* *}$ \\
(4) Kültür Etkisi (\%) & - & - & - & - \\
\hline
\end{tabular}

*, **: istatistiki önemlilik derecesi sırasıyla; $\mathrm{P}<0.01$ ve $\mathrm{P}<0.05$.

*, **: Significantly different from zero at $\mathrm{P}<0.01$ and $\mathrm{P}<0.05$ probability, respectively. 
benzerlik göstermektedir. Kallus oluşumu ile kallus ağırlığ arasındaki önemli pozitif $\left(\mathrm{r}=0.339^{*}\right)$ ilişki, kallus ağırlı̆̆ 1 ile rejenerasyon kapasitesi $(\mathrm{r}=-0.422)$ ve kallus ağırlığı ile kültür etkisi $(r=-0.405)$ parametreleri arasında ise istatistiki olarak $(\mathrm{P}<0.05)$ önemli ve negatif ilişki tespit edilmiştir. Kallus oluşumu ve kallus ağırlığı arasındaki önemli ve olumlu ilişkiyi gösteren bulgularımız, ekmeklik buğdayda $(\mathrm{r}=0.662)$ (Ahmet ve Adak 2007), yulafta ( $\mathrm{r}=0.870)$ (Birsin ve ark. 2001), tritikalede ( $\mathrm{r}=0950)$ (Birsin ve Özgen 2004) ve misırda (Akınyosoye ve ark. 2014) ve aegilopsda ( $\mathrm{r}=0.820$ ) (Özgen ve ark. 2017) yapılan çalışmalarla örtüşmektedir.

\section{Sonuçlar}

Sonuç olarak; makarnalık buğdayda olgun embriyoların doku kültürü parametrelerine tepkisini belirlemek için yapılan bu çalışmada, kallus oluşumu, kallus ağırlı̆̆ı, bitki rejenerasyonu ve kültür etkisi üzerinde genotipin önemli ölçüde etkili olduğu ortaya çıkmıştır. Genetik mühendisliği teknikleri ile buğdaya gen aktarma çalışmalarında başarı iyi ve etkili bir rejenerasyon sistemi gerektirmektedir. Olgun embriyo kültürü buğdaya gen aktarma çalışmalarında yeterli rejenerasyon kapasitesi sağlayabilecektir. Bu nedenle, yıl boyunca kolayca bulunabilen olgun embriyolar, buğday doku kültüründe etkili bir eksplant kaynağı olarak kullanılabilecektir.

Ayrıca denemelerde kullanılan makarnalık buğday çeşitlerinden doku kültürü koşullarında rejenerason yeteneği en yüksek olan çeşitlerin sirasıyla; Berkmen-469, Kızıltan-91 ve Eminbey (Şekil 1 ve Şekil 2) olduğu belirlenmiştir. Bu çeşitler, genom düzenleme bileşenlerini veya transgenik dizileri kodlayan yapıların sağlanması için ana hedef olan embriyogenik kallus üretme ve rejenere olabilme konusunda kayda değer bir yetenek göstermiştir ve doğrudan gen aktarılabilme potansiyellerinin diğer makarnalık buğday çeşitlerine göre daha yüksek olduğu görülmüştür. $\mathrm{Bu}$ çeşitlerin biyoteknolojik yöntemlerle dayanıklı çeşit geliştirilmesine taban oluşturabilecek çeşitler olduğu yorumu yapılabilmektedir.
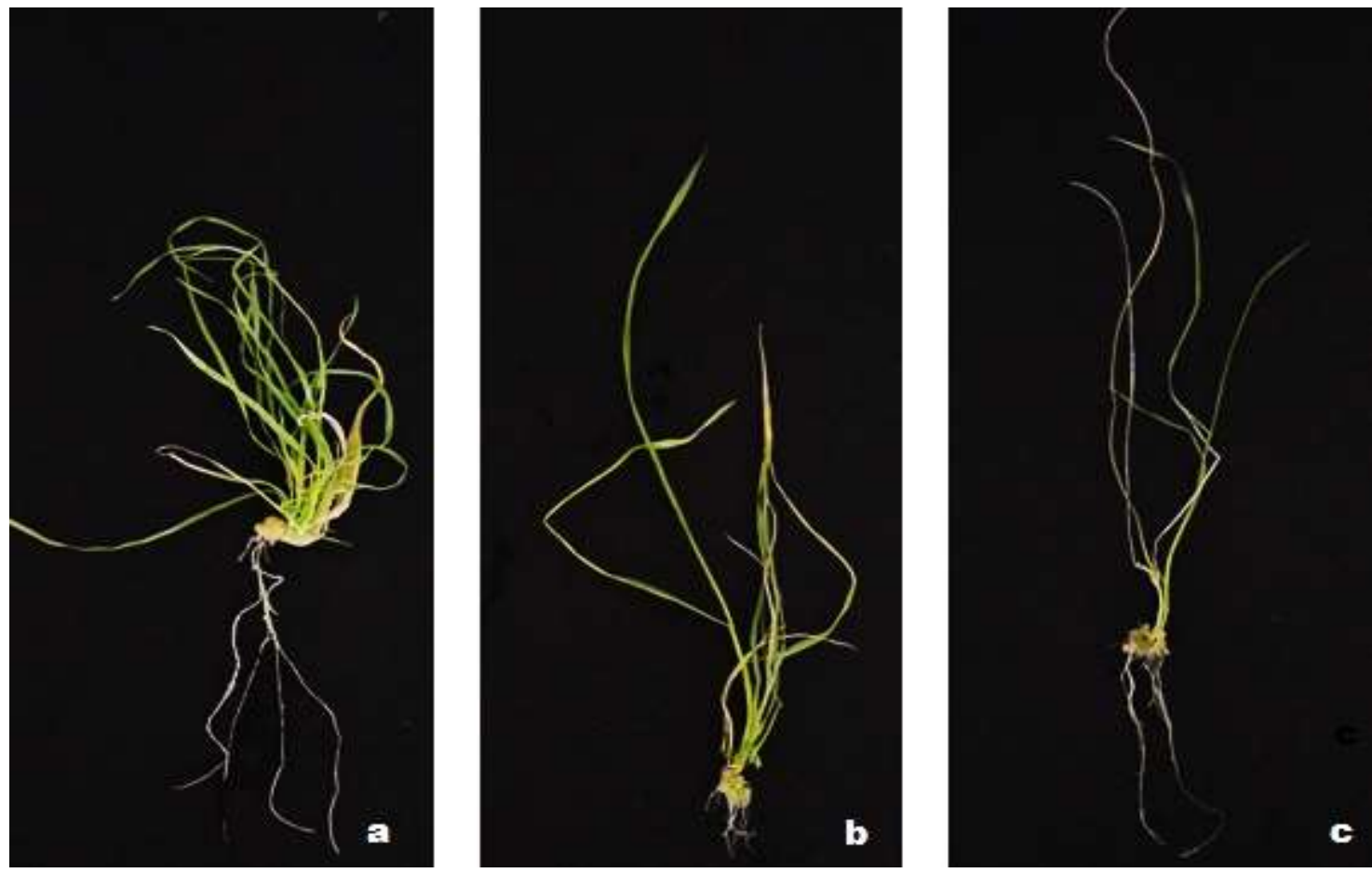

Şekil 2. Makarnalık buğday çeşitlerinin rejenerantları (a: Berkmen-469, b: Kızıltan-91 ve c: Eminbey).

Figure 2. Regenerants of durum wheat cultivars (a: Berkmen-469, b: Kızıltan-91 ve c: Eminbey).

\section{Kaynaklar}

Aadel H, Ahansal K, Udupa SM, Gaboun F, Abdelwahd R, Douira A, Iraqi D (2016) Effect of genotypes and culture media on embryogenic callus induction and plantlet regeneration from mature and immature bread wheat embryos. Agricultural Research 33: 6169.

Acar H (2006) Kışlık buğdayın (Triticum sp.) in vitro koşullarda vernalizasyonu. Doktora Tezi, Ankara Üniversitesi Fen Bilimleri Enstitüsü, Ankara.

Ahmet H, Adak MS (2007) Irak’ta yetiştirilen bazı ekmeklik buğday çeșitlerinde kallus oluşumu ve bitki rejenerasyonu. Tarım Bilimleri Dergisi 13: 285-292.

Akinyosoye ST, Adetumbi JA, Amusa OD, Olowolafe MO, Olasoji JO (2014) Effect of seed size on in vitro seed germination, seedling growth, embryogenic callus induction and plantlet regeneration from embryo of maize (Zea mays L.) seed. Nigerian Journal of Genetics 28(2): 1-7.

Bajji M, Lutts S, Kinet JM (2000) Physiological changes after exposure to and recovery from polyethylene glycol-induced water deficit in callus cultures issued from durum wheat (Triticum durum Desf.) cultivars differing in drought resistance. Journal of Plant Physiology 156(1): 75-83.

Birsin MA, Önde S, Özgen M (2001) Callus induction and plant regeneration from mature embryos of oat (Avena sativa L.). Turkish Journal of Biology 25: 427-434.

Birsin M, Özgen M (2004) A comparison of callus induction and plant regeneration from different embryo explant of Triticale. Cellular \& Molecular Biology Letters 9: 353-361.

Bozkurt M (2012) Türkiye dünya durum buğdayı üretiminde üçüncü. Ekmek, Bisküvi ve Makarna Sektörü İhtisas Dergisi 1: 74-75. 
Delporte F, Pretova A, Du Jardin, P, Watillon B (2014) Morphohistology and genotype dependence of in vitro morphogenesis in mature embryo cultures of wheat. Protoplasma 251: $1455-1470$.

$\begin{array}{lllll}\text { FAO (2019) Plant production } & \text { statistics. }\end{array}$ http://www.fao.org/faostat/en/\#data/QC. Erişim 20 Şubat 2019.

Farshadfar E, Jamshidi B, Cheghamirza K, Hashemzadah H (2012a) Evaluation of drought tolerance in breat wheat (Triticum aestivum L.) using immature embryo culture. Annals of Biological Research 3(1): 330-338.

Farshadfar E, Jamshidi B, Cheghamirza K, Teixeira da Silva JA (2012b) Evaluation of drought tolerance in bread wheat (Triticum aestivum L.) using in vivo and in vitro techniques. Annals of Biological Research 3(1): 465-476.

Gonzales JM, Friero E, Jouve N (2001) Influence of genotype and culture medium on callus formation and plant regeneration from immature embryos of Triticum turgidum desf. cultivars. Plant Breeding 120: 513-517.

Grigoryeva LP, Shletser IA (2006) Screening wheat cultivars for morphogenesis ability in immature embryo culture in vitro. Biologia 3: 64-66.

Hakam N, Udupa SM, Gaboun F, Rabha A, Ibriz M, Iraqi D (2014) Effect of genotypes and culture media on embryogenic callus induction and plantlet regeneration from mature embryos of durum wheat. Romanian Agricultural Research 31: 121-128.

Haliloğlu K (2002) Wheat immature embryo culture for embryogenic callus induction. Journal of Biological Sciences 2(8): 520-521.

İbrahim AS (2012) An efficient regeneration system via somatic embryogenesis in some egyptian durum wheat cultivars mediated high-throughput transformation of durum wheat using Agrobacterium tumefaciens. Research Journal of Agriculture and Biological Sciences 8(3): 369-384.

Jasdeep P, Avijit T, Varsha S, Harinder V, Sanjay S (2019) Cultivar specific response of callus induction and plant regeneration from mature embryos in different elite Indian wheat. Research Journal of Biotechnology 14(2): 1-8.

Mahmood IA, Razzaqand Z, Khan U (2012) Evaluation of tissue culture responses of promising wheat (Triticum aestivum L.) cultivars and development of efficient regeneration system. Pakistan Journal of Botany 44(1): 277- 284.

Malik K, Birla D, Yadav H, Sainger M, Chaudhary D, Jaiwal PK (2017) Evaluation of carbon sources, gelling agents, growth hormones and additives for efficient callus induction and plant regeneration in Indian wheat (Triticum aestivum L.) genotypes using mature embryos. Journal of Crop Science and Biotechnology 20(3): 185192.

Miroshnichenko DN, Klementyeva AA, Salina EA, Dolgov SV (2019) Evaluation of in vitro plant regeneration efficiency in Siberian wheat cultivars. Current Challenges in Plant Genetics, Genomics, Bioinformatics and Biotechnology 24: 126-128.
Murashige T, Skoog F (1962) A revised medium for rapid growth and bioassays with tobacco tissue cultures. Physiologia Plantarum 15: 473-497.

Özgen M, Türet M, Özcan S, Sancak C (1996) Callus induction and plant regeneration from immature and mature embryos of winter durum wheat genotypes. Plant Breeding 115: 455-458.

Özgen M, Türet M, Altınok S, Sancak C (1998) Efficient callus induction and plant regeneration from mature embryo culture of winter wheat (Triticum aestivum L.) genotypes. Plant Cell Reports 18(3-4): 331-335.

Özgen M, Türet M, Avcı M (2001) Cytoplasmic effects on the tissue culture response of callus from winter wheat mature embryos. Plant Cell, Tissue Organ Culture 64: 81-84.

Özgen M, Avcı Birsin M, Benlioğlu B (2017) Biotechnological characterization of a diverse set of wheat progenitors (Aegilops sp. \& Triticum sp.) using callus culture parameters. Plant Genetic Resources: Characterization \& Utilization 15(1): 45-50.

Pellegrineschi A, Brito RM, Mclean S, Hoisington D (2004) Effect of 2,4- Dichlorophenoxyacetic acid and $\mathrm{NaCl}$ on the establishment of callus and plant regeneration in durum and bread wheat. Plant Cell, Tissue and Organ Culture 77: 245-250.

Przetakiewicz A, Orczyk W, Nadolska-Orczyk A (2003) The effect of auxin on plant regeneration of wheat, barley and Triticale. Plant Cell, Tissue and Organ Culture 73: 245-256.

Sayar MT, Birsin MA, Ulukan H, Özgen M (1999) Effect of seed size on the tissue culture response of callus from mature embryos of wheat species. Wheat Information Service 89: 1-6.

Steel RG, Torrie JH, Dickey DA (1980) Principles and procedures of statistics: a biometrical approach (Vol. 633). New York, USA: McGraw-Hill, New York.

Swati S, Priya AK, Manoj KY (2019) Development of drought tolerant wheat through mutagenic and plant tissue culture tools. International Research Journal of Biological Sciences 1: 4-12.

Tuberosa R, Rauaglia S, Lucchese C (1998) Callus induction and plant regeneration in Italian cultivars of bread wheat. Agricultural Medicine 18: 361-365.

TUIK (2019) "Bitkisel Üretim İstatistikleri". https://biruni.tuik.gov.tr/medas/?kn=92\&locale=tr. Erişim 20 Şubat 2019.

Witrzens B, Brettell RI, Murray FR, McElroy D, Li Z, Dennis ES (1998) Comparison of three selectable marker genes for transformation of wheat by microprojectile bombardment. Functional Plant Biology 25(1): 39-44.

Zale JM, Wier HB, Kidwell KK, Steber CM (2003) Callus induction and plant regeneration from mature embryos of a diverse set of wheat genotypes. Plant Cell, Tissue and Organ Culture 76: 277281 . 